\title{
Study of Growth, Yield and Quality of Some Tomato Varieties in Valley Soils of Chittagong
}

\author{
M. G. Kibria ${ }^{1}$, M. Islam ${ }^{2}$ and K. T. Osman ${ }^{3}$ \\ ${ }^{1,2,3}$ Department of Soil Science, University of Chittagong, Chittagong 4331, Bangladesh
}

\begin{abstract}
A field experiment was conducted at Research Field of Department of Soil Science, University of Chittagong, Bangladesh to study growth, yield and quality of ten improved varieties of tomato (CLN3125A, CLN3125E, CLN3125L, CLN3125O, CLN3125P, CLN3125Q, CLN3070J, CLN3078A, CLN3078C, CLN3078G) of the Asian Vegetable Research and Development Centre, Taiwan and five varieties (BARI-3, BARI-8, BARI-9, BARI-14, BARI-15) released by Bangladesh Agricultural Research Institute, Joydevpur. It was observed that plant height, number of branches and number of leaves varied from 50 to $80 \mathrm{~cm}, 8$ to 19 and 112 to 282 at 30 days after transplantation (DAT) and 64 to $100 \mathrm{~cm}, 19$ to 29 and 307 to 612 at 45 DAT, respectively. The number of fruits plant ${ }^{-1}$ ranged from 19 to 52 and single fruit weight of tomato varied from $35.04 \mathrm{~g}$ to $72.05 \mathrm{~g}$. The yield of tomato varied from 36.36 ton ha $\mathrm{ho}^{-1}$ to 122.21 ton ha-1 among the varieties. Results further depicted that in respect of yield and quality, CLN3125P was found to be the best suitable and promising variety for growing in the valley soil of Chittagong. Similar result was found with CLN3125E, CLN3125L CLN3078J and BARI tomato 15. Results enumerated that quality of tomato varieties in terms of total soluble sugar, reducing sugar and non reducing sugar, vitamin $C$ and nutrient minerals also showed significant variations.
\end{abstract}

Key words: Plant height, yield, total soluble sugar, vitamin C, nutrient content.

\section{Introduction}

Tomato (Lycopersicon esculentum P. Mill) is one of the most popular and widely grown vegetables in the world. It is consumed either raw as salad or cooked. It is used for seasoning vegetables, curries and to impart them special colour, flavour, taste and is used in many other ways. Tomato outranks all others in terms of total contribution of vitamins and minerals to the diet mainly because of the large volume consumed both in fresh and processed forms. It is adapted to wide range of soils and grown abundantly during winter season in Bangladesh. However, in Bangladesh average yield of tomato is very low as compared to neighboring country like India and Pakistan [1]. Higher production of tomato depends upon adoption of high yielding varieties, appropriate crop management practices and balanced fertilization, timely irrigation, control of diseases and insect pests. Because of its prime importance in human diet and great demand tremendous efforts have been made to improve and develop new cultivars of high yielding and good quality.

It is important to know the suitable cultivar giving good results according to the existing climatic conditions to get higher yield. Bangladesh has a wide range of soils. In the high hill ranges, the soils are very shallow to deep, pale brown, slightly to strongly acidic, sandy loams to clays, usually overlying decomposing bedrocks at variable depths. The hilly areas cover about 1,734,182 ha mostly in the Greater districts of Chittagong Hill Tracts, Chittagong and Sylhet [2]. Climate is alternating hot, humid in the rainy season and cool, dry in the winter season. Rainfall exhibits considerable spatial variations within short distances and ranges from an annual average of 1,200 $\mathrm{mm}-4,500 \mathrm{~mm}$ [2]. In hilly areas of Chittagong tomato is also grown on small scale as market gardening and a local cultivar is adopted in the area. In this area local germ plasm is not suitable for cultivation because of low yield and inferior quality and farmers are dependent on the unreliable seed available in the market. The imported seed is available but has not been tested in the local environmental conditions to know the suitability of the cultivar for this area. The present work is an attempt to select some improved (in respect of yield and quality) varieties of tomato suited to our local environment.

\section{1. Field experiment}

\section{Materials and Methods}

A field experiment was conducted at research field of Department of Soil Science, University of Chittagong, Bangladesh to study the performance of fifteen improved varieties of tomato. Seeds of ten (CLN3125A, CLN3125E, CLN3125L, CLN3125O, CLN3125P, CLN3125Q, CLN3070J, CLN3078A, CLN3078C, CLN3078G,) improved tomato varieties have been collected from the Asian Vegetable Research and Development Centre, Taiwan and five (BARI-3, BARI-8, BARI-9, BARI-14, BARI-15) from Bangladesh Agricultural Research Institute, Joydevpur for the present study. Seeds were sown in the nursery separately for each variety. Complete germination of the seeds took place within 10 days after sowing. Healthy and uniform sized of about one month old seedlings were transplanted in the main plots. A light irrigation was done 
immediately after transplanting. The distance between rows to row was $50 \mathrm{~cm}$ and seeding to seedling was 40 $\mathrm{cm}$. Irrigation was applied as and when necessary. Different intercultural operations were accomplished as and when necessary for better growth and development of plants. After ploughing and laddering all the stubbles, crop residues and uprooted weeds were collected and removed from the main field and the land was ready. Whole experimental land was divided into unit plots maintaining the desired spacing. The whole area of the experimental plot was divided into 3 blocks and each block was again divided into 15 unit plots for the 15 varieties. Thus the treatments (variety) were replicated three times. The experiment was laid out in a randomized complete block design (RCBD). The size of the unit plot was $2 \mathrm{~m}$ length and $2 \mathrm{~m}$ width. Block to block and plot to plot distance were $0.5 \mathrm{~m}$ and $0.5 \mathrm{~m}$ respectively. Fertilizers were applied according to the Fertilizer Recommendation Guide [3] at the rate of N $100 \mathrm{~kg} \mathrm{ha}^{-1}, \mathrm{P} 30 \mathrm{~kg} \mathrm{ha}^{-1}$ and $\mathrm{K} 60 \mathrm{~kg} \mathrm{ha}^{-1}$ as urea, triple super phosphate (TSP) and muriate of potash (MOP), respectively equally to the soil in each plot. Full phosphorus was incorporated during final land preparation. Nitrogen and potassium was applied in two equal installments at 15 and 35 days after transplantation as ring method around the plants followed by irrigation.

The experimental soil was clay loam (33\% sand, $19 \%$ silt and $48 \%$ clay) with $\mathrm{pH} 5.10$, organic matter content $1.32 \%$, cation exchange capacity (CEC) $8.76 \mathrm{cmol} \mathrm{kg}^{-1}$, total nitrogen $0.12 \%$, and available P (Olsen P) $14 \mathrm{mg} \mathrm{kg}^{-1}$. Soil texture was determined by hydrometer method [4], soil $\mathrm{pH}$ was measured in a 1:2.5 soil/water suspension with glass electrode $\mathrm{pH}$ meter, organic carbon by wet-oxidation method [5], total nitrogen by microKjeldahl digestion and distillation and $\mathrm{CEC}$ by $1 \mathrm{~N} \mathrm{NH}_{4} \mathrm{OAC}$ saturation [6], and available phosphorus by Olsen method [7].

\section{2. Determination of growth and yield components}

Plant height, number of branches plant ${ }^{-1}$ and number of leaves plant ${ }^{-1}$ were recoded after 30 and 45 days after transplantation (DAT). The number of fruits plant ${ }^{-1}$, single fruit weight, and yield per unit area were recorded during harvest.

\section{3. Determination of nutritional quality of tomato}

Total soluble sugar, reducing sugar and non reducing sugar of ripe fruits were estimated by standard method of analysis as described by Shahnawaz et al. [8]. Vitamin C content was determined by the method as described by Jideani and Onwubali [9]. Plant material (tomato fruit) was digested in $\mathrm{H}_{2} \mathrm{SO}_{4}+\mathrm{H}_{2} \mathrm{O}_{2}+\mathrm{Se}$ mixture [10] to extract the nutrients. Nitrogen from extract was determined by micro-Kjeldahl distillation [6], phosphorus by vanadomolybdate yellow color method [6], and potassium, calcium and magnesium with an atomic absorption spectrophotometer.

\section{4. Statistical Analysis}

The data collected was subjected to analysis of variance, and treatment means were compared using Duncan's Multiple Range Test (DMRT) at 5\% probability level.

\section{Results and Discussion}

\section{1. Growth and yield}

Plant height varied from 50 to 80 at 30 days after transplantation (DAT) and 64 to $100 \mathrm{~cm}$ at 45 DAT. The average number of branches plant ${ }^{-1}$ ranged significantly from 8 to 19 and 19 to 29 at 30 and 45 DAT, respectively. The average number of leaves plant ${ }^{-1}$ at 30 and 45 DAT varied significantly from 112 to 282 and 307 to 612 , respectively (Table 1). Total number of fruits plant ${ }^{-1}$ ranged from 19 to 52 , single fruit weight of tomato was from $35.04 \mathrm{~g}$ to $72.05 \mathrm{~g}$ and yield of tomato varied from 36.36 ton ha ${ }^{-1}$ to 122.21 ton ha ${ }^{-1}$ among the varieties (Table 2). Moisture and dry matter content in different varieties of tomato ranged from 94.23 to 97.33 $\%$ and 2.76 to $5.79 \%$ respectively (Table 2 ).

The results of the present study indicated that there were significant variations in growth of plants among tomato varieties in terms of plant height, number of branches and number of leaves. Considering all the varieties CLN3125O was the tallest plant at 30 DAT; and BARI tomato-14 was the shortest. The highest plant height at 45 DAT was recorded in CLN3125O and the lowest plant height was recorded in BARI tomato-8.

The highest number of branches plant ${ }^{-1}$ was recorded in CLN3078C at 30 DAT and in CLN3078A at 45 DAT while the varieties CLN3125O and BARI tomato 8 performed the lowest in comparison with other varieties at 30 and $45 \mathrm{DAT}$, respectively. The highest number of leaves plant ${ }^{-1}$ was recorded in CLN3125P and CLN3078A at 30 and 45 DAT and the lowest number of leaves plant ${ }^{-1}$ was recorded in varieties CLN3125O and CLN3070J at 30 and 45 DAT, respectively. Number of fruits plant ${ }^{-1}$ and single fruit weight are the most important yield attributing characters of tomato plant. The parameters showed statistical significant variation among the varieties. The highest number of fruits plant ${ }^{-1}$ was observed in variety CLN3125L and the lowest number of fruits plant ${ }^{-1}$ was found in variety BARI tomato 14 . However, the number of fruits plant ${ }^{-1}$ was 
statistically similar among the varieties CLN3125L, CLN3125A, CLN3125E, CLN3125O, CLN3125P, CLN3070J, CLN3078A, CLN3078C, CLN3078G and BARI tomato 15. It was observed that only BARI tomato 15 of the local varieties showed similarity with most of the exotic varieties in producing number of fruits plant ${ }^{-1}$. Hossain et al. [11] reported that the number of fruits plant ${ }^{-1}$ varied from 12.50 to 45.43 in 8 varieties of tomato. Similar result was also reported by Arun et al. [12]. The highest single fruit weight was found in variety CLN3125A and the lowest single fruit weight was found in variety CLN3078G. The single fruit weight of the varieties CLN3125A, CLN3125Q, BARI tomato 3 and BARI tomato 14 was statistically similar. Hossain et al. [11] reported that BARI tomato 7 gave the highest weight of single fruit when six tomato mutants viz. TM-13, TM-105, TM-110, TM-133, TM -152, TM-155 and two varieties BARI tomato 7 and BARI tomato 5 were grown in the Bangladesh Institute of Nuclear Agriculture (BINA) sub station farm, Rangpur.

Table1. Plant height, number of branches and number of leaves of tomato varieties grown in valley soil of Chittagong

\begin{tabular}{lllllll}
\hline \multirow{2}{*}{ Tomato variety } & \multicolumn{2}{l}{ Plant height $(\mathrm{cm})$} & \multicolumn{2}{l}{$\begin{array}{l}\text { Number of branches } \\
\text { plant }^{-1}\end{array}$} & \multicolumn{2}{l}{ Number of leaves plant ${ }^{-1}$} \\
\cline { 2 - 6 } & $30 \mathrm{DAT}$ & $45 \mathrm{DAT}$ & $30 \mathrm{DAT}$ & $45 \mathrm{DAT}$ & $30 \mathrm{DAT}$ & $45 \mathrm{DAT}$ \\
\hline CLN3125A & $55 \mathrm{bcd}$ & $87 \mathrm{abc}$ & $14 \mathrm{bcd}$ & $27 \mathrm{ab}$ & $163 \mathrm{bcd}$ & $587 \mathrm{ab}$ \\
CLN3125E & $69 \mathrm{abc}$ & $90 \mathrm{abc}$ & $9 \mathrm{ef}$ & $26 \mathrm{abc}$ & $127 \mathrm{~d}$ & $476 \mathrm{abcd}$ \\
CLN3125L & $52 \mathrm{~cd}$ & $90 \mathrm{abc}$ & $18 \mathrm{ab}$ & $29 \mathrm{a}$ & $206 \mathrm{abcd}$ & $530 \mathrm{abc}$ \\
CLN3125O & $80 \mathrm{a}$ & $100 \mathrm{a}$ & $9 \mathrm{ef}$ & $23 \mathrm{~cd}$ & $112 \mathrm{~d}$ & $447 \mathrm{abcd}$ \\
CLN3125P & $71 \mathrm{ab}$ & $89 \mathrm{abc}$ & $16 \mathrm{abc}$ & $23 \mathrm{~cd}$ & $282 \mathrm{a}$ & $602 \mathrm{a}$ \\
CLN3125Q & $65 \mathrm{abcd}$ & $91 \mathrm{abc}$ & $8 \mathrm{f}$ & $26 \mathrm{abc}$ & $160 \mathrm{bcd}$ & $390 \mathrm{bcd}$ \\
CLN3070J & $67 \mathrm{abc}$ & $87 \mathrm{abc}$ & $11 \mathrm{def}$ & $22 \mathrm{de}$ & $143 \mathrm{~cd}$ & $307 \mathrm{~d}$ \\
CLN3078A & $65 \mathrm{abcd}$ & $95 \mathrm{ab}$ & $15 \mathrm{abc}$ & $29 \mathrm{a}$ & $264 \mathrm{ab}$ & $612 \mathrm{a}$ \\
CLN3078C & $67 \mathrm{abc}$ & $92 \mathrm{abc}$ & $19 \mathrm{a}$ & $28 \mathrm{ab}$ & $159 \mathrm{bcd}$ & $485 \mathrm{abcd}$ \\
CLN3078G & $49 \mathrm{~d}$ & $78 \mathrm{bcd}$ & $15 \mathrm{abc}$ & $22 \mathrm{de}$ & $184 \mathrm{abcd}$ & $575 \mathrm{ab}$ \\
BARI tomato-3 & $76 \mathrm{a}$ & $93 \mathrm{ab}$ & $14 \mathrm{bcd}$ & $27 \mathrm{ab}$ & $249 \mathrm{abc}$ & $326 \mathrm{~cd}$ \\
BARI tomato-8 & $55 \mathrm{bcd}$ & $64 \mathrm{~d}$ & $13 \mathrm{~cd}$ & $19 \mathrm{e}$ & $135 \mathrm{~cd}$ & $447 \mathrm{abcd}$ \\
BARI tomato-9 & $54 \mathrm{bcd}$ & $65 \mathrm{~d}$ & $13 \mathrm{~cd}$ & $25 \mathrm{bcd}$ & $174 \mathrm{abcd}$ & $386 \mathrm{bcd}$ \\
BARI tomato-14 & $50 \mathrm{~d}$ & $72 \mathrm{~cd}$ & $13 \mathrm{~cd}$ & $22 \mathrm{de}$ & $160 \mathrm{bcd}$ & $299 \mathrm{~d}$ \\
BARI tomato-15 & $70 \mathrm{abc}$ & $89 \mathrm{abc}$ & $16 \mathrm{abc}$ & $23 \mathrm{~cd}$ & $205 \mathrm{abcd}$ & $341 \mathrm{~cd}$ \\
Significance of F & 0.01 & 0.01 & 0.001 & 0.001 & 0.05 & 0.01 \\
value & & & & & & \\
\hline
\end{tabular}

Figures in the column having the same letter (s) are statistically similar according to DMRT at $\mathrm{P} \leq 0.05$

Table 2. Number of fruits, single fruit weight, yield, moisture content and dry matter content of tomato varieties grown in valley soil of Chittagong.

\begin{tabular}{|c|c|c|c|c|c|}
\hline Tomato variety & $\begin{array}{l}\text { Number of } \\
\text { fruits plant }\end{array}$ & $\begin{array}{c}\text { Single fruit } \\
\text { weight }(\mathrm{g})\end{array}$ & $\begin{array}{l}\text { Yield } \\
\left(\text { ton }^{-1} a^{-1}\right)\end{array}$ & $\begin{array}{l}\text { Moisture } \\
\text { content }(\%)\end{array}$ & $\begin{array}{l}\text { Dry matter } \\
\text { content }(\%)\end{array}$ \\
\hline CLN3125A & 32 abcde & $72.05 \mathrm{a}$ & $64.46 \mathrm{bcd}$ & $97.23 \mathrm{a}$ & $2.76 \mathrm{~b}$ \\
\hline CLN3125E & 42 abcd & 58.38 bcde & $103.80 \mathrm{ab}$ & $96.43 \mathrm{a}$ & $3.57 \mathrm{ab}$ \\
\hline CLN3125L & $52 \mathrm{a}$ & $36.95 \mathrm{~h}$ & $92.30 \mathrm{abc}$ & $94.23 \mathrm{a}$ & $5.79 \mathrm{a}$ \\
\hline CLN3125O & 40 abcde & 45.65 efgh & $85.33 \mathrm{abcd}$ & $96.33 \mathrm{a}$ & $3.65 \mathrm{ab}$ \\
\hline CLN3125P & $49 \mathrm{ab}$ & 55.09 bcde & $122.21 \mathrm{a}$ & $96.10 \mathrm{a}$ & $3.88 \mathrm{ab}$ \\
\hline CLN3125Q & 26 cde & $65.18 \mathrm{ab}$ & $82.64 \mathrm{abcd}$ & $95.87 \mathrm{a}$ & $4.14 \mathrm{ab}$ \\
\hline CLN3070J & 39 abcde & $51.70 \mathrm{cdef}$ & $97.22 a b c$ & $96.37 \mathrm{a}$ & $3.61 \mathrm{ab}$ \\
\hline CLN3078A & 33 abcde & $37.84 \mathrm{gh}$ & $48.05 \mathrm{~cd}$ & $95.53 \mathrm{a}$ & $4.46 \mathrm{ab}$ \\
\hline CLN3078C & $45 a b c$ & $40.64 \mathrm{fgh}$ & $74.51 \mathrm{abcd}$ & $96.73 \mathrm{a}$ & $3.26 \mathrm{~b}$ \\
\hline CLN3078G & $49 \mathrm{ab}$ & $35.04 \mathrm{~h}$ & $74.39 \mathrm{abcd}$ & $95.87 \mathrm{a}$ & $4.11 \mathrm{ab}$ \\
\hline BARI tomato-3 & 26 cde & $64.78 \mathrm{abc}$ & $84.45 \mathrm{abcd}$ & $97.33 \mathrm{a}$ & $2.65 \mathrm{~b}$ \\
\hline BARI tomato- 8 & $22 \mathrm{de}$ & 50.48 defg & $51.26 \mathrm{bcd}$ & $95.53 \mathrm{a}$ & $4.45 \mathrm{ab}$ \\
\hline BARI tomato- 9 & 29 bcde & $33.61 \mathrm{~h}$ & $36.36 \mathrm{~d}$ & $96.43 \mathrm{a}$ & $3.55 \mathrm{ab}$ \\
\hline BARI tomato-14 & $19 \mathrm{e}$ & $59.97 \mathrm{abcd}$ & $51.10 \mathrm{bcd}$ & $97.00 \mathrm{a}$ & $3.02 \mathrm{~b}$ \\
\hline BARI tomato-15 & $46 a b c$ & 46.49 efgh & $102.64 \mathrm{ab}$ & $96.47 \mathrm{a}$ & $3.54 \mathrm{ab}$ \\
\hline $\begin{array}{l}\text { Significance of } F \\
\text { value }\end{array}$ & 0.01 & 0.001 & 0.05 & NS & 0.05 \\
\hline
\end{tabular}

Figures in the column having the same letter (s) are statistically similar according to DMRT at $\mathrm{P} \leq 0.05$. NS=Not Significant 
Yield is the most important characteristic for the justification of evaluation of tomato genotypes and varieties. The tomato varieties under this study showed significant variation in producing yield. The variety CLN3125P produced the highest yield and BARI tomato 9 produced the lowest yield. However, the yield of tomato varieties CLN3125P, CLN3125E, CLN3125L, CLN3125O, CLN3125Q, CLN3070J, CLN3078C, CLN3078G, BARI tomato 3 and BARI tomato 15 were similar. It was observed that BARI tomato 15 showed the best performance in producing yield among the local varieties while CLN3125P performed the best among the exotic varieties. Although the single fruit weight of BARI tomato 15 was smaller than that of BARI tomato 3, BARI tomato 8 and BARI tomato 14; but it produced the highest value of yield among the local varieties due to the largest number of fruits plant ${ }^{-1}$. Among the exotic varieties, though the fruit size of CLN3125A was the largest; but it did not produce the highest yield due to less number of fruits plant ${ }^{-1}$. The range of yield was reported to be 40.73 - 60.59 ton ha ${ }^{-1}$ in 8 varieties of tomato by Hossain et al [11]. The tomato varieties showed significant variation in dry matter content but not in moisture content. The variety CLN3125L had the highest dry matter content while CLN3125E, CLN3125O, CLN3125Q, CLN3070J, CLN3078A, CLN3078G, BARI tomato 8, BARI tomato 9 and BARI tomato 15 had the similar value of dry matter content; CLN3125A had the lowest value of dry matter content. Hossain et al. [11] also found the less variation in dry matter content among the different varieties.

\section{2. Quality of tomato}

The total soluble sugar, reducing sugar and non reducing sugar content of tomato varied from 2.25 to $4.47 \%, 1.35$ to $3.15 \%$ and 0.60 to $1.27 \%$, respectively (Table 3). The vitamin C (ascorbic acid) content was found to be 17.32 to $26.64 \mathrm{mg} 100 \mathrm{~g} \mathrm{~g}^{-1}$ in different tomato varieties (Table 3). The nutrients $\mathrm{N}, \mathrm{P}, \mathrm{K}, \mathrm{Ca}$ and $\mathrm{Mg}$ content of different varieties of tomato ranged from 2.81 to $3.94 \%, 33$ and $0.58 \%, 1.95$ to $4.42 \%, 0.04$ to 0.28 $\%$ and 0.13 to $0.18 \%$ respectively (Table 4 ).

Quality of tomato varieties in terms of total soluble sugar, reducing sugar and non reducing sugar, vitamin $\mathrm{C}$ and nutrient minerals showed significant variations. The highest soluble sugar content was found in variety CLN3125P followed by CLN3125Q and CLN3070J, and the lowest soluble sugar content was found in variety BARI tomato 3. It was observed that all the exotic varieties except CLN3125A contained higher amounts of total soluble sugar compared to that of local varieties. BARI tomato 9 contained the highest amount of total soluble sugar among the local varieties. In the present study, the variety CLN3125Q contained the highest amount of reducing sugar. Similar result was found with CLN3125P. The lowest reducing sugar content was found in BARI tomato 3. It was evident from the data in Table 3, that the reducing sugar content of tomato fruits like total soluble sugar was maintained higher in the exotic varieties when compared with the local varieties. The highest non reducing sugar content was found in CLN3125P and the lowest non reducing sugar content was found in BARI tomato 8 and BARI tomato 14. Tadesse et al. [13] reported that reducing sugar content in 10 ten tomato varieties ranged from 1.13 to $2.27 \%$. However, in a study by Ereifej et al. [14], reducing sugar content in seven tomato cultivars ranged from 1.1 to 4.1 .

Table 3. Total soluble sugar, reducing sugar, non reducing sugar and vitamin $\mathrm{C}$ of tomato varieties grown in valley soil of Chittagong.

\begin{tabular}{lllll}
\hline Tomato variety & $\begin{array}{l}\text { Total soluble } \\
\text { sugar }\end{array}$ & $\begin{array}{l}\text { Reducing } \\
\text { sugar }\end{array}$ & $\begin{array}{l}\text { Non- reducing } \\
\text { Sugar }\end{array}$ & Vitamin C \\
\hline CLN3125A & $3.35 \mathrm{f}$ & $2.36 \mathrm{~g}$ & $0.95 \mathrm{~d}$ & $23.20 \mathrm{~cd}$ \\
CLN3125E & $3.61 \mathrm{e}$ & $2.67 \mathrm{e}$ & $0.88 \mathrm{de}$ & $24.23 \mathrm{bc}$ \\
CLN3125L & $4.10 \mathrm{c}$ & $2.95 \mathrm{c}$ & $1.09 \mathrm{c}$ & $23.25 \mathrm{~cd}$ \\
CLN3125O & $4.14 \mathrm{c}$ & $2.98 \mathrm{c}$ & $1.10 \mathrm{bc}$ & $24.69 \mathrm{~b}$ \\
CLN3125P & $4.47 \mathrm{a}$ & $3.14 \mathrm{a}$ & $1.27 \mathrm{a}$ & $26.34 \mathrm{a}$ \\
CLN3125Q & $4.36 \mathrm{~b}$ & $3.15 \mathrm{a}$ & $1.15 \mathrm{bc}$ & $23.20 \mathrm{~cd}$ \\
CLN3070J & $4.30 \mathrm{~b}$ & $3.06 \mathrm{~b}$ & $1.18 \mathrm{~b}$ & $17.40 \mathrm{~g}$ \\
CLN3078A & $3.37 \mathrm{~d}$ & $2.83 \mathrm{~d}$ & $0.90 \mathrm{de}$ & $23.14 \mathrm{~cd}$ \\
CLN3078C & $3.65 \mathrm{e}$ & $2.68 \mathrm{e}$ & $0.92 \mathrm{de}$ & $21.66 \mathrm{ef}$ \\
CLN3078G & $3.85 \mathrm{~d}$ & $2.88 \mathrm{~d}$ & $0.92 \mathrm{de}$ & $23.28 \mathrm{~cd}$ \\
BARI tomato-3 & $2.25 \mathrm{i}$ & $1.35 \mathrm{j}$ & $0.85 \mathrm{e}$ & $18.69 \mathrm{~g}$ \\
BARI tomato-8 8 & $2.65 \mathrm{~h}$ & $2.02 \mathrm{i}$ & $0.60 \mathrm{f}$ & $18.35 \mathrm{~g}$ \\
BARI tomato-9 & $3.37 \mathrm{f}$ & $2.46 \mathrm{f}$ & $0.86 \mathrm{de}$ & $22.16 \mathrm{de}$ \\
BARI tomato-14 & $2.64 \mathrm{~h}$ & $2.01 \mathrm{i}$ & $0.60 \mathrm{f}$ & $20.65 \mathrm{f}$ \\
BARI tomato-15 & $2.78 \mathrm{~g}$ & $2.08 \mathrm{~h}$ & $0.67 \mathrm{f}$ & $21.24 \mathrm{ef}$ \\
Significance of F value & 0.001 & 0.001 & 0.001 & 0.001 \\
\hline \multicolumn{2}{r}{ Figures in the column having the same letter (s) are statistically similar according to DMRT at P $\leq 0.05}$. \\
\hline
\end{tabular}


Table 4. Nutrient content of tomato varieties grown in valley soil of Chittagong

\begin{tabular}{llllll}
\hline Tomato Variety & $\mathrm{N}$ & $\mathrm{P}$ & $\mathrm{K}$ & $\mathrm{Ca}$ & $\mathrm{Mg}$ \\
\hline CLN3125A & $3.94 \mathrm{a}$ & $0.57 \mathrm{a}$ & $3.91 \mathrm{abc}$ & $0.26 \mathrm{ab}$ & $0.18 \mathrm{a}$ \\
CLN3125E & $3.77 \mathrm{ab}$ & $0.58 \mathrm{a}$ & $3.74 \mathrm{abc}$ & $0.22 \mathrm{abcd}$ & $0.18 \mathrm{a}$ \\
CLN3125L & $3.36 \mathrm{bcdef}$ & $0.52 \mathrm{abcd}$ & $2.37 \mathrm{de}$ & $0.11 \mathrm{cde}$ & $0.14 \mathrm{a}$ \\
CLN3125O & $2.81 \mathrm{f}$ & $0.50 \mathrm{abcde}$ & $3.38 \mathrm{abcd}$ & $0.28 \mathrm{a}$ & $0.17 \mathrm{a}$ \\
CLN3125P & $3.18 \mathrm{cdef}$ & $0.52 \mathrm{abcd}$ & $3.35 \mathrm{abcd}$ & $0.04 \mathrm{f}$ & $0.13 \mathrm{a}$ \\
CLN3125Q & $3.56 \mathrm{abcd}$ & $0.57 \mathrm{a}$ & $3.61 \mathrm{abc}$ & $0.13 \mathrm{cde}$ & $0.17 \mathrm{a}$ \\
CLN3070J & $2.89 \mathrm{ef}$ & $0.39 \mathrm{bcde}$ & $3.25 \mathrm{abcd}$ & $0.19 \mathrm{abcd}$ & $0.14 \mathrm{a}$ \\
CLN3078A & $3.71 \mathrm{abc}$ & $0.53 \mathrm{abc}$ & $3.09 \mathrm{bcd}$ & $0.22 \mathrm{abcd}$ & $0.14 \mathrm{a}$ \\
CLN3078C & $3.79 \mathrm{ab}$ & $0.56 \mathrm{ab}$ & $3.87 \mathrm{abc}$ & $0.09 \mathrm{ef}$ & $0.16 \mathrm{a}$ \\
CLN3078G & $3.25 \mathrm{bcdef}$ & $0.33 \mathrm{e}$ & $2.80 \mathrm{cde}$ & $0.18 \mathrm{abcd}$ & $0.14 \mathrm{a}$ \\
BARI tomato-3 & $3.56 \mathrm{abcd}$ & $0.36 \mathrm{de}$ & $4.42 \mathrm{a}$ & $0.09 \mathrm{ef}$ & $0.15 \mathrm{a}$ \\
BARI tomato-8 & $3.02 \mathrm{def}$ & $0.37 \mathrm{cde}$ & $1.95 \mathrm{e}$ & $0.25 \mathrm{abc}$ & $0.15 \mathrm{a}$ \\
BARI tomato-9 & $3.78 \mathrm{ab}$ & $0.38 \mathrm{cde}$ & $3.18 \mathrm{bcd}$ & $0.27 \mathrm{a}$ & $0.16 \mathrm{a}$ \\
BARI tomato-14 & $3.41 \mathrm{abcde}$ & $0.47 \mathrm{abcde}$ & $4.00 \mathrm{ab}$ & $0.23 \mathrm{abcd}$ & $0.17 \mathrm{a}$ \\
BARI tomato-15 & $3.03 \mathrm{def}$ & $0.54 \mathrm{abc}$ & $3.09 \mathrm{bcd}$ & $0.26 \mathrm{ab}$ & $0.16 \mathrm{a}$ \\
Significance of F & 0.001 & 0.01 & 0.01 & 0.01 & $\mathrm{NS}$ \\
value & & & & & \\
\hline
\end{tabular}

Figures in the column having the same letter (s) are statistically similar according to DMRT at $\mathrm{P} \leq 0.05$.

NS=Not Significant

The variety CLN3125P has the highest vitamin C content and CLN3070J has the lowest vitamin C content. Similar to this study, Anita [15] and Thakur and Kaushal [16] reported that vitamin C content ranged

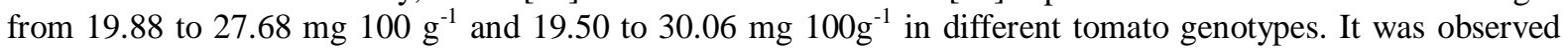
from this study that the exotic varieties contained significantly higher vitamin $\mathrm{C}$ content when compared to that of the local varieties. However, the exotic variety CLN3070J was statistically similar to the local varieties BARI tomato 3 and BARI tomato 8 .

Nutrient content in different varieties of tomato showed significant variation except $\mathrm{Mg}$. The highest $\mathrm{N}$ content was found in CLN3125A among the tomato varieties. The nitrogen content found in CLN3125Q, CLN3078A, CLN3078C, BARI tomato 3, BARI tomato 9 and BARI tomato 14 was statistically similar to that of CLN3125A. The lowest N content was found in variety CLN3125O. The highest content of P was found in CLN3125E and this value was statistically similar to that found in CLN3125A, CLN3125L, CLN3125O, CLN3125P, CLN3125Q, CLN3078A, CLN3078C, BARI tomato 14 and BARI tomato 15. The lowest P content was found in variety CLN3125G. The phosphorus content obtained in the tomato was close to the value reported earlier by Loiudice et al.[17] and Shibli et al. [18] who reported 0.45 to $0.59 \%$ and 0.46 to $0.71 \%$ of phosphorus on dry matter basis in different varieties of tomatoes, respectively. The highest $\mathrm{K}$ content was found in BARI tomato 3 and the lowest $\mathrm{K}$ content was found in BARI tomato 8. However, $\mathrm{K}$ content in CLN3125A, CLN3125E, CLN3125O, CLN3125P, CLN3125Q CLN3070J, CLN3078C, BARI tomato 3 and BARI tomato 15 were statistically similar. The highest content of Ca was observed in CLN3125O, while CLN3125A, CLN3125E, CLN3070J, CLN3078A, CLN3078G, BARI tomato 8, BARI tomato 9, BARI tomato 14 and BARI tomato 15 had the similar value of Ca content. The variety CLN3125P had the lowest value of Ca content.

\section{Conclusions}

Considering all the varieties CLN3125O had the highest plant height, CLN3078A had the highest number of branches plant ${ }^{-1}$ and the highest number of leaves plant ${ }^{-1}$; while the highest number of fruits plant ${ }^{-1}$ was observed in CLN3125L. CLN3125P showed the best performance in producing yield. Similar yield was found with exotic varieties CLN3125E, CLN3125L CLN3078J and the local variety BARI tomato 15. CLN3125P had the highest sugar and vitamin C content. Therefore, the exotic variety CLN3125P may be considered as the best suitable among the varieties studied for growing in the valley soils of the Chittagong in respect of yield and quality. The exotic varieties CLN3125E, CLN3125L CLN3078J and the local variety BARI tomato 15 are also suitable for growing in this region. Further research is needed to increase the yield and to improve the quality of these varieties.

\section{Acknowledgement}

The authors wish to thank Development and Planning Office of the University of Chittagong for providing financial support to carry out this research. 


\section{References}

[1] N. K. Halder, M. K. Saha, A. H. M. F. Kabir, J. U. Sarker and M. J. Rahman, Response of summer tomato to hormone and planting time at hill slope, Pakistan Journal of Biological Sciences, 6(2), 2003, 146-148.

[2] S. M Saheed, Status of Human-Induced Soil Degradation in Bangladesh. Country Report, Expert Consultation of the Asian Network on Problem Soils, 1995, FAO, Manila, Philippines.

[3] BARC (Bangladesh Agricultural Research Council), Fertilizer Recommendation Guide (Dhaka, BARC Soils Publication No.45, 2005)

[4] P. R. Day, Particle fractionation and particle size analysis, in C. A. Black (Ed.) Methods of Soil Analysis. Part I. Agronomy Monograph, (New York: Academic Press, 1965) 545-567.

[5] A. Walkley and I. A. Black, An examination of the Degtjareff method for determining organic carbon in soils: Effect of variations in digestion conditions and of inorganic soil constituents, Soil Science, 63, 1934, 251-263.

[6] M L. Jackson, Soil Chemical Analysis (New Delhi, Prentice Hall of India Private Limited, 1973).

[7] S. Olsen, C. Cole, F. Watanabe and L. Dean, Estimation of available phosphorus in soils by extraction with sodium bicarbonate (USDA Circular No. 939, US Government Printing Office, Washington, D.C., 1954).

[8] M. Shahnawaz, S. A. Sheikh and S. M. Nizamani, Determination of Nutritive Values of Jamun Fruit (Eugenia jambolana) Products, Pakistan Journal of Nutrition, 8(8), 2009, 1275-1280.

[9] V. A. Jideani and F. C. Onwubali, Optimization of wheat-sprouted soybean flour bread using response surface methodology, African Journal of Biotechnology, 8 (2), 2009, 6364-6373.

[10] S. E. Allen, H. M. Grimshaw and A. P. Rowland, Chemical analysis, In P. D. Moore and S. B. Chapman (Eds.), Methods in Plant Ecology (Oxford: Blackwell Scientific Publications, 1986) 285-344.

[11] M. E. Hossain, M. J. Alam, M. A. Hakim, A. S. M Amanullah and A. S. M. Ahsanullah, Assessment of physicochemical properties of some tomato genotypes and varieties grown at Rangpur, Bangladesh Research Publication Journal, 4(3), 2010, 235243.

[12] J. Arun, V. Amit and M. C. Thakur, Studies on genetic variability, correlation and path analysis for yield and physico-chemical fraits in tomato, Progressive Horticulture, 36(1), 2004, 51-58.

[13] T. Tadesse, T. S. Workneh and K. Woldetsadik, Effect of varieties on changes in sugar content and marketability of tomato stored under ambient conditions, African Journal of Agricultural Research, 7(14), 2012, 2124-2130.

[14] K. I. Ereifej, R. A. Shibli, M. M. Ajlouni and A. Hossain, Physico-chemical characteristics and processing quality of newly introduced seven tomato cultivars into Jordan in comparison with local variety, Journal of Food Science and. Technology, 34(2), 1997, 171-174.

[15] K. Anita, Nutritive value and processing of tomatoes for its effective utilization, M. Sc Thesis, Department of Food Nutrition, CCS Haryana Agricultural University, Hisar, India, 1997.

[16] N. S. Thakur, and B. B. Kaushal, Study of quality characteristics of some commercial varieties and F, hybrids of tomato (Lycnpersicon esculentujn Mill) grown in Himachal Pradesh in relation to processing, Indian Food Packer, 49(3), 1995, 25-31.

[17] R. Loiudice, M. Impembo, B. Laratta, G. Villari, A. Lovoi, P. Siviero and D. Castaldo, Composition of San Marzano Tomato Varieties, Food Chemistry, 53, 1995, 81-89.

[18] R. A. Shibli, K. I Ereifej, M. A. Ajlouni and A. Hussain, Physico-chemical properties of fruits of four open pollinated tomato (Lycopersicon esculentum Mill . ) cultivars grown under rainfed conditions in Jordan, Journal of Food Science and Technology, 32(6), 1995, 489-492. 